i kierowanym przez dyrektora o pełnej, znaczącej osobowości. Pomocą okaże się samokształcenie poprzedzone odpowiednim zorganizowaniem warsztatu pracy. Ułatwić to moga organizacja nauczycielska, czasopismo pedagogiczne, kontakty między nauczycielami, wymiana zdobytych doświadczeń.

We Wrocławiu niewątpliwie lepiej zrozumiał teoretyczne założenia i praktyczną realizację idei pietystów i pestalocystőw oraz rolę szkoły elementarnej jako jednej z głównych podstaw dalszej edukacji człowieka.

Slawomir Sztobryn

Lódź

\title{
Badania nad Filozofią Pedagogii Józefa Hoene-Wrońskiego w czasopiśmiennictwie pedagogicznym w latach 1918 - 1939
}

Literatura poświęcona temu równie wybitnemu co kontrowesyjnemu filozofowi $w$ badanej przestrzeni czasowej nie jest obfita, a mimo to bogatsza niż współcześnie. Spośród dziewiętnastowiecznych filozofów-pedagogów właśnie on konstruowal najbardziej hermetyczną $i$ uniwersalną wizję świata, człowieka i jego rozwoju. Wtórowali mu B. F. Trentowski, A. Cieszkowski, K. Libelt, ale żaden $z$ nich nie szedł $w$ swych koncepcjach tak daleko.

Międzywojenne czasopiśmiennictwo nawiązywało do wybitnych postaci zazwyczaj w związku $z$ jakąś określoną rocznicą Tak było i w przypadku Wrońskiego, choć jego popularność w niektórych kręgach intelektualnych była szczególna. Rozprawy powstawały krótko przed, jak i po 150 rocznicy urodzin (1928). Pisane były przez znanych filozofów (Jastrzębiec-Kozłowski), jak i pedagogów (Rowid). Wroński zainteresował także prof. literatury porównawczej na Sorbonie - Fernanda Baldenspergera oraz Franka Walsera, którego rozprawa została przełożona z języka francuskiego.

Spośród czasopism, na lamach których podejmowano badania nad filozofią wychowania Hoene-Wrońskiego, tylko właściwie jedno - Minerwa Polska - posiadało orientację historyczno-pedagogiczną. Inne, takie jak Ruch Pedagogiczny czy Miesięcznik Pedagogiczny nastawione były bardziej na najnowsze zagadnienia pedagogiczne. Jeszcze bardziej odległy od ujęć historycznych był Przeglad Wspólczesny, natomiast w ramach Sprawozdań z Czynności i Posiedzeń PAU prezentowane były prace różnych komisji - w przypadku Wrońskiego - Komisji do Badania Dziejów Filozofii w Polsce.

Dająca się dostrzec różnorodność punktów widzenia uniemożliwia odnalezienie jakiegoś wspólnego wszystkim autorom kryterium historycznego, natomiast wydaje się, że sprzyjała utwierdzeniu więzi filozofii i pedagogiki, mimo znaczącego ożywienia badań eksperymentalnych prowadzonych w oparciu o dynamicznie rozwijającą się psychologię i socjologię. Rzadko spotyka się w literaturze, szczególnie w czasopiśmiennictwie, aby każde kolejne ujęcie odznaczało się odmiennością punktu widzenia, odwoływało się do różnych momentów twórczości danego filozofa czy pedagoga. Drugim znamiennym rysem jest, odmienne niż zazwyczaj, postawienie badań biograficznych (które nota bene sq w tym przypadku rzeczywiście frapujące) na drugim miejscu a skoncentrowane są na doksografii.

Ożywienie zainteresowania Wrońskim nastąpiło po 1920 roku kiedy rozpoczęto prace translatorskie (do dziś nie ukończone) ${ }^{1}$. Jest to zaskakujące, bowiem obok Trentowskiego, był on uważany za najwybitniejszy „polski umysł filozoficzny”. Postrzegano go nawet jako rodzimego Sokratesa ale $z$ tragicznym rysem - nigdy nie wykształcił swego Platona. Jako niepospolita

${ }^{1}$ H. Rowid, Idealy wychowawcze w filozofii polskiej. „Miesięcznil Pedagogiczny” 1925, T. 34, \&. 259. 
osobowość został uwieczniony pod postacią Grodnińskiego w powieści Balzaka Komedia Ludzka². W tym miejscu trzeba więc postawić pytanie: czego właściwie szukano w twórczości Wrońskiego, skąd ten nagły - a dziś z perspektywy czasu możemy dodać krótkotrwały - wybuch zainteresowania. Pierwszą istotniejszą wskazówkę znajdziemy w pracy S. Kolbuszewskiego. Jego zdaniem dopiero Wroński podjął się sformułowania uniwersalnego (w przeciwieństwie do koncepcji monistycznych i dualistycznych) celu pedagogiki. Herbart - najbardziej wpływowy pedagog XIX wieku - uznany został przez niego za subiektywistę w zakresie celów wychowania, a jego koncepcja za wtórną wobec pedagogiki I. Kanta. Prezentowany autor dostrzegł w twórczości B. Trentowskiego podobny uniwersalny motyw, ale jego „bóstwo in actu" nie miało tej pełni co autokreacja w doktrynie Wrońskiego ${ }^{3}$. Wedhug Kolbuszewskiego nikt przed Wrońskim nie postawił tak problemu wychowania, można więc przypuszczać, że ten filozof otwierał nową epokę w dziejach polskiej myśli pedagogicznej. Dla odrodzonej pedagogiki międzywojennej takie ujęcie musialo być atrakcyjne nie tylko swą oryginalnością ale i konsekwencjami teoretycznymi. Czy jednak ugruntowanie podstaw pedagogiki w absolutnym celu ludzkości (efekt badań historiozoficznych Wrońskiego) nie mieściło się w kolejnym romantycznym micie. Tak chyba oceniał Kolbuszewski jądro filozofii Wrońskiego, twierdząc, że: „sedno jego filozofii lepiej między bajki włożyćn ${ }^{n-4}$ I choć to krytyczne sformułowanie wydaje się słuszne, to przecież nie sposób odmówić Wrońskiemu wpływu na potomnych. Poza wspomnianym Balzakiem oddziałał na poezję Baudelaira, muzykę Durutte’a. Natomiast w Polsce trudno wskazać, szczególnie pedagoga, który by wyszedł od jego systemu w poszukiwaniu własnej teorii pedagogicznej. Intrygujący ale niezrozumiały, krytyczny wobec tego świata i nazbyt wybiegający w świat, do którego kluczem miało być niemal pitagorejskie wtajemniczenie, Wroński walczył ze wszystkim i wszystkimis. Ta postawa, mimo wielu bardzo celnych i oryginalnych poglądów pedagogicznych - wyniosła go właściwie poza nawias intelektualistów Europy.

Zagadnieniem, które we współczesnej pedagogice na nowo odżywa jest związek filozofii i pedagogiki. W naszym stuleciu jest to już drugi taki nawrót, pierwszy swe apogeum osiągnął przed Il wojną światową. Zobaczymy wiẹc jak ten związek postrzegano $w$ świetle prac Wrońskiego. H. Rowid, zgadzając się z Trentowskim, uważał, że „filozofia jest kluczem do świątyni pedagogiki"6. Samego zaś Wrońskiego stawiał obok takich, zapisanych w dziejach pedagogiki filozofów, jak: Platon, Arystoteles, Locke, Rousseau, Herbart. Brak tu I. Kanta, z którym z kolei zestawił go Baldensperger. Żaden jednak $\mathrm{z}$ analizowanych tu autorów nie pokusił się o określenie prądu (kierunku) w pedagogice, którego wyrazicielem byłby Wroński. Można jedynie przypuszczać, że zaliczano go do wewnętrznie bardzo zróżnicowanego nurtu pedagogiki filozoficznej. Niemniej, wskazując na genezę czy analogie z określoną orientacją filozoficzną, nie uczyniono tego w odniesieniu do pedagogiki. Czy takie egzemplaryczne potraktowanie Wrońskiego jest merytorycznie słuszne i metodologicznie poprawne pozostaje problemem otwartym.

Najwięcej uwagi filozofii pedagogiki Wrońskiego poświęcił Kolbuszewski. Artykułując kolejne momenty w systemie Wrońskiego zgadzal się, by to filozofia określała podstawy pedagogiki - oczywiście chodzi tu o totalnz, uniwersalną filozofię - bo tylko ona może określić powszechny, nieredukowalny dalej cel ludzkości, a więc i cel wychowania. Wszyscy, spośród badanych autorów, jednoglośnie powtarzają za Wrońskim, że tym celem powszechnym jest samo-tworzenie, autokreacja ludzkości.

${ }^{2}$ F. Baldensperger, Hoene-Wroński a Francja intelektualna „Przeglad Wspólczesny" 1928, T. XXV. A. Walicli twierdzi, że „byl an protolypem postaci Wrońskiego w powiéci Balzaka La Recherche de l'absolu”; S. Borzym, H. Floryńska, B. Skarga, A Walicki, Zarys dziejów filozofii polskiej 1815-1918. Warszawa 1986, \&. 23. Można dostrzec w nim także "polskjego Humboldta”, piszqcego z wewnęlrznej potrzeby poznania PRAWDY, na dalszy plan odsuwajgcoga komunikowanie swych zawilych tconii współcossnym. Pisal bardziej dla siebie niż innych, pozostajq̨ w zgodzie częaln tylko z samym sobeq.

'S. Kolbuszewskj, Filoroficzne podlozie pedagogiki Hoene-Wrońskiegn. „Mincrwa Polska" 1927, nf 2, s $143-144$.

4 Ibidem, 8155.

9 Między innymi miał zhtarg z matematykami i inżynicrami francuskimi. Przeciwstawil się ówczesnemu słowianofilstwu - atakując przy okazji A. Mickiewicza - niechętnie wyrażal się a prolestantach i jezujtach. F. Baldensperger, op. cit, s. 16-20.

"H. Rowid, Idealy wychowawcze w filozofii polskiej. „Miesięcznil Pedagogiczny" 1925, T. 34, s. 259. 
Kolbuszewski zwrócił jednak uwage na bardzo ważną myśl Wrońskiego, który najprawdopodobniej jako pierwszy wskazał na niejednoznaczny charakter tej dyscypliny. „Problem wychowania nie jest jeszcze rozwiązany - a co ważniejsze, dodaje Kolbuszewski, nie jest dotąd ustalony. (...) Tymczasem filozofia dotychczas nic na tym polu nie uczyniła, gdyż wszystkie jej wskazania dadzą się sprowadzić do uwag, że należy rozwijać w człowieku zespół wladz jego cielesnych i duchowych. W ślad za tym nakazuje filozofia czerpać prawidła wychowania a posteriori w psychologii i somatologii, a priori zaś w moralności i filozofii religii. Wynikiem tego NIEOKRESLLNOSC POJĘCIA PEDAGOGII, stąd nieokreśloność środków jakimi trzeba sprawować wychowanie"t?. Pedagogika więc - i myśl tę można uznać za współczesną - musi najpierw dokładnie sprecyzować swój przedmiot, pojęcia, ich zakres, potem dopiero sugerować określony transfer wartości. Choć żaden z prezentowanych autorów wyraźnie tego nie powiedzial, wydaje się, że w polskiej pedagogice od Wrońskiego (jak w niemieckiej od Herbarta) rozpoczyna się świadome, naukowe podejście do pedagogiki. Wyższość Wrońskiego - co dostrzega Kolbuszewski - nad minionymi i współczesnymi myślicielami polega na próbie sharmonizowania całej ludzkości w jeden organizm, gdy wszyscy inni relatywizowali swe poglądy do wyraźnie określonego miejsca i czasu. Nawet chrześcijaństwo, które Kolbuszewski, błędnie prezentuje jako nośnik ogólnoludzkiego celu, w swych dziejach reinterpretowało swe pierwotne posłanie. Zbieżność z Herbartem dostrzegal w tzw. "tablicy genetycznej pedagogii”, gdzie pojęcie „humanistyka" skojarzone zostało $\mathrm{z}$ neohumanistycznym programem ksztalcenia.

U Wrońskiego znajdujemy sąd - typowy chyba dla uczonych o filozoficznym wykształceniu i niemal identycznie sformulowany przez Hessena, nieznanego jeszcze szerszemu ogółowi polskich humanistów początku XX wieku - że: „pedagogia będzie mogla czerpać z historii filozofii wskazania, jakie były cele względne okresów minionych (...) historia filozofii pouczy ją o nowych drogach i wzniesie przed nia przyszłe kolejne cele"?.

Wszyscy niemal uczeni interpretujący lub tylko opisujący poglądy Wrońskiego jednogłośnie wskazują na jego Prawo Postępu jako powszechny drogowskaz rozwoju ludzkości i wychowania. Jaka jest więc wykładnia tego prawa u badanych autorów?

U Kolbuszewskiego akcent został położony na syntezie w absolucie tego co względne, jedności prawa i dobra. W ten sposób odpowiedzi na problem źródeł wychowania udzielić może refleksja filozoficzna (historia filozofii) uprawiana w duchu Wrońskiego. W miejsce chronologicznego porządkowania kolejnych doktryn Wroński chce wprowadzić analizę genetyczną, którą zasadą miało być jego Prawo Tworzenia. Dostrzegl to Kolbuszewski, bowiem preferował w twórczości Wrońskiego wartości formalne: systemowość i metodę jako rzeczywiste wartości tej doktryny".

Najwięcej uwagi Prawu Postępu poświęcił filozof Cz. Jastrzębiec-Kozłowski. Jego regułą heurystyczną służącą wyznaczeniu treści Prawa Postępu było określenie: 1. „funkcji wolności równoznacznej z koniecznością" i 2. „funkcji konieczności równoznacznej z wolnością"10. Omawiane prawo według tego autora odpowiada drugiej funkcji. Jego zdaniem, jak wolnośc odpowiada konieczności, tak samo wolności usystematyzowanej, czyli Prawu Tworzenia, winna odpowiadać konieczność usystematyzowania - czym jest właśnie Prawo Postępu... Prawo Postępu jest tedy zespołem celów. Rządzona przezeń konieczność działa niejako automatycznie choć celowo, niby zegar, gdy tymczasem Prawo Tworzenia można by porównać z budowaniem czy nakręcaniem

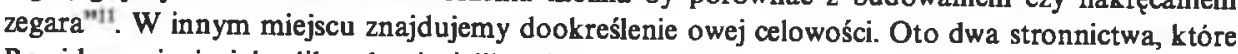
Rowid wymienia jako liberalne i nieliberalne, mają jako swój cel odpowiednio Prawdę i Dobro.

'S. Kalhuszewski, op.cit, \& 139.

"Ihidem, s. 147 .

9. P. Chomicz dając w 24 tezach elemcnty Prawa Tworzenia umieszcza w nich Prawo Postępu wiłżąc je z celami rozumowymi ludzkosci. Prawo to jest wyktadniq̨ historiozofii Wrońskjego. Natomiust w pracach Baldenspergera i Rowida nie zostalo ono uwzględnione, mimo iz odgrywa ono istotnq rolę w architek tonice doktryny. P. Chomic,, Hoene-Wrońskiego Prawo Stworzenia jako podstawa reformy wiedzy ludzkiej. „Sprawozdania z Czynności i Posiedzeń PAU” 1927, nr 6.

${ }^{10} \mathrm{Cz}$ Jastrzębiec-Kozlowski, Hoene-Khońskiego filozofia pedagogii. "Ruch Pedagogiczny” 1932, nr 7, s. $196-197$
${ }^{11}$ Ibidem, s. 197. 
Ujęcie jednak tych wartowści w kategoriach absolutnych ujawnia ich jedność, a one same są warunkami stworzenia się czlowieka i w tym tkwi ich sens pedagogiczny. Prawda i Dobro w swej absolutnej postaci są wspólne dla całej ludzkości, a stan ten Jastrzębiec-Kozłowski za Wrońskim nazywal mesjanistycznością.

Zastanówmy się obecnie nad zasadami pedagogiki Hoene-Wrońskiego, a więc tym, co stanowi oś konstrukcji jego doktryny. Zdaniem Kolbuszewskiego - widzacego we Wrońskim jednego z geniuszy romantyzmu - cała jego filozofia wychodzi i zmierza ku jednej zasadzie wyrażonej w Prawie Tworzenia. Tą ostateczną zasadą jest rozum absolutny, dzięki któremu mógł Wroński zbudować teorię odrodzenia ludzkości i człowieka jako jednostki. Zasada ta jest więc immanentną częścią jego teorii pedagogicznej ${ }^{12}$. Dzięki takiemu postawieniu problemu Wroński zmierzał do uwolnienia pedagogiki od wszystkiego co dowolne, subiektywne, różnicujące. Jego konstrukcja filozoficzna pozwalała mu (krytykę pozostawiamy na koniec) widzieć w pedagogice po pierwsze dyscyplinę naukowa, po wtóre - naukę opartą na tym, co ostatecznie i bezwyjątkowo wspólne dla wszystkich ludzi. I, co warto podkreślić, uczeni analizujący tę doktrynę zauważyli, że to co wspólne nie jest ani natury materialnej, ani socjalnej. Cechą konstytutywną ludzkości jest zdolność tworzenia - element stwórczy w świecie stworzonym, jak później wypowiedział tę samą myśl Trentowski.

$\mathrm{Na}$ inny, rzekłbym platoński, aspekt powyższego zagadnienia zwrócił uwage $\mathrm{F}$. Walser: „Filozofia Wrońskiego (...) wykazuje $z$ niezbitą siłą, że istota rozumna, która to postać jest cechą "wyróżniającą człowieka, zależy ściśle od równowagi. W pracy wychowawczej zmysł równowagi górować powinien ponad wszystkim"13. I choć cytowany fragment u Walsera skierowany jest na dookreślenie pracy wychowawcy, znajdującego harmonię w odpowiednim łączeniu doświadczenia (empiria) i myślenia (abstrakcja), to przecież myśl tę można uogólnić i odnieść do całości systemu Wrońskiego. Aby uniknąć różnorodnych - ,izmów", trzeba szukać równowagi u samych podstaw nauki o wychowaniu. Antropologiczna wizja człowieka jako homo creator - wydawałoby sie tak nowa, wspólczesna - jest punktem wyjścia refleksji pedagogicznej Hoene-Wrońskiego.

Kolejne zagadnienie, które wybitnie przyciągnęło uwage badaczy, to kwestia celu wychowania. $\mathrm{Z}$ racji toczących się $\mathrm{w}$ okresie międzywojennym dyskusji na ten temat, było to zagadnienie szczególnie ważne i inspirujące ówczesne przemyślenia. W trzech, spośród badanych prac, dostrzeżono że cel wychowania człowieka wywiedziony został nie z koncepcji psychologicznych czy poglądów socjologicznych lecz konsekwentnie jest wyrazem historiozofii Wrońskiego. W dziele Philosophie Absolue de l'Histoire tak oto wyrazil on swą myśl: „żaden z różnorakich celów, włącznie z celem religii, do których ludzkość zmierzała kolejno od swego zarania aż do dni naszych, nie posiada wartości absolutnej, tzn. זzeczywistości niewarunkowej, czyli istniejącej przez się (...) Tak tedy, ludzkość nie posiada jeszcze istnienia własnego; stanowi ona jeszcze, jak rzekliśmy, igraszkę celowości nieznanej; a dla osiągnięcia godności istnienia absolutnego, które bezspornie jest przeznaczeniem ziemi, ludzkość winna dokonać odrodzenia lub raczej prawdziwego stworzenia siebie samej, wytyczając cel najwyższy swego istnienia"14. Jak widzimy jest tu zupełnie wyraźna zbieżność z kantowskim pojęciem oświecenia. Autorzy referując poglądy Wrońskiego zgodnie twierdza, że tak jak w dziejach ludzkości istniały epoki, tak poprzez wynikanie odpowiadają im określone cele ${ }^{15}$. W erze fizycznej dominować miały cele względne, w erze rozumu - absolutne. Te pierwsze - w kontekście teleologii Wrońskiego - są mało interesujące, można by rzec, iż są to cele negatywne. $W$ jaki więc sposób cel pozytywny przenika $z$ historiozofii do pedagogiki? Odpowiedź

12 Zarówno Kolbuszewski, jak Jastrzębiec-Kozlowski zwracaja uwage na nienkreśloność podsław pedagogikj, dosirzeżona przez Wrońskiego. Wyprowadzznie pedagogiki z przesłanek psychologicznych, lizjologicznych, etycznych czy religijnych nie alanowi o ich obiektywności. Zauważmy, ze nowe wychowanie zatacza to kamo kało w oparciv o naukj w ich ówczesnej, glebszej postaci. Dychotomia i następstwo subicktywizmu i obiektywizmu jest także problemem najblizszej przyszłoáci.

13 F. Walscr, Wychowanie kierowane wedtug filozofii Hoene-Wron'skiegn. .Ruch Pedsgogiczny" 1930, nr S, s. 247. "Wychowa nie Lakie, kierowane przez. prawa wazechświala, nje będzie a ni stronniczym, a ni powic rzchownym, nie bedze mialo specjalnej tendencji ani uparlych pojóc, wyzbyte bẹdzje pychy narodowej, narodowych czy innych przesqdów"; ibidem, \& 200.

${ }^{14} \mathrm{Cz}$ Jasirzęiec-Kozlowski, op. citu s 199.

Is Ibidem, \& $198-199,201$, 229; H. Rowid, op. ciL \& 260; S. Kolbunzewski, op. cil, \& 145. 
na to pytanie przemilczano, jedynie Jastrzębiec-Kozłowski nie wdając się $w$ interpretacje Wronskiego, długimi cytatami usiłuje przybliżyć jego myśl. Odpowiedzią na wyżej sformułowane pytanie jest myśl Wronskiego, iż wychowanie powinno mieć ten sam cel (zadanie) co i ludzkość. Prawa jego filozofii (Postępu, Tworzenia) są zarazem - „w sposób naturalny” - prawami pedagogiki. Przy takim postawieniu zagadnienia granica między filozolią a pedagogika przestaje istniec, a pedagogika ulega redukcji do filozofii. Pedagogika Wrońskiego okazuje się filozofia zastosowaną do wychowania człowieka. Żaden jednak z autorów nie podjął tej kwestii, przyjmując - jak moźna sądzić - jako naturalną jedność obu, dziś samodzielnych dyscyplin.

W związku z tym problemem ciekawe spostrzeżenie znajdujemy u Kolbuszewskiego. Zazwyczaj o wychowaniu się myśli przez odniesienie do konkretnej czasoprzestrzeni. Tymczasem prawdziwe wychowanie, według Wronskiego, jest niczym nieuwarunkowane, uwolnione od kategorii fizycznych, z konieczności wydaje się wyrazem jakiegoś absolutnego funkcjonalizmu. Bowiem tym pozytywnym, ostatecznym celem wychowania jest autokreacja, samorzutnosk. I słusznie twierdzi Walser, ze wychowanie CZLOWIEKA usuwa skrajne stanowiska pedagogiczne, ale pojawia się problem innego rodzaju: czy tak pozaczasowo i pozaprzestrzennie ujęty człowiek nie okaże się chimerą, mitem, abstrakcją?".

Rowid usiłował zinterpretować ową autokreację, i chyba bez powodzenia, ponieważ nadał jej cechy zdroworozsądkowe odwołując się do XX wiecznej szkoły twórczej. Pisał tak: „Jak bowiem rozumieć naleźy "stworzenie się własne człowieka?” Jest to nic innego (podkr. S. Sz.), jak tylko budzenie tych energii $i$ sił potencjalnych tkwiących w duszy wychowanka, które mu umożliwiają ciągle doskonalenie się wewnętrzne, które go uzdolnią do działania produktywnego, do życia nieust.annie tworzącego nowe wartości materialne $i$ duchowe"17. Błąd tego autora polega na tym, że pojẹcie ducha ujął w kategoriach psychologicznych (a więc w myśl Wrońskiego jednostronnie, skrajnie), gdy tymczasem ten mesjanista w duchu widział „to, co myśli”, „ducha świata”. Latwo to dostrzec czytając pracę Rowida w odwróconym porządku. Oto stworzenie się człowieka jest wyrazem jego duchowego odrodzenia, a to z kolei wyrasta z poznania absolutnej PRAWDY 1 DOBRA. Rowid podobnie jak Kolbuszewski i inni autorzy odwołuje się do jedności obu ustalonych pierwiastków - odwzorowanej w jedności filozofii i religii - ale nadał im inne znaczenie niž Wronski ${ }^{18}$. Ten drugi, wydaje się glębiej $\mathrm{i}$ bardziej w zgodzie z Wrońskim pojął jego filozofię wychowania. Omawiając szczeble świadomości - o których za chwilę - pisał tak: „Swiadomość geniusza; przez nią pozna człowiek końcowy zbieg fillozofii i religii, czyli ziści w sobie Słowo. I ja muszą wszyscy posiąsć; dotychczas spełniło się to w Chrystusie i - we Wrońskim, który odkrył współzbieg filozofí i religii. Ostatecznie najwyższa jest świadomość absolutna (..) gdyż przez nią odkryje (człowiek) absolut i stworzy się sam"19. Kobluszewski subtelnie zagłębiając sį w retorykę Wronskiego zwraca uwagę na pewien rys jego dokryny, który oświetla jego osobowość. Można by to nazwac swoistym „egalitaryzmem perfekcjonizmu” - myśl, która na kanwie nowej psychologii $\mathrm{XX}$ wieku pojawila się jako teoria rekapitulacji. Wychowanie odwzorujące Prawo Postępu i Tworzenia zapewnić miało interioryzacje tradycji kulturowej i wniknięcie „w pierwotną tożsamośc Bytu i Słowa". Wroński swym niepospolitym umysłem ogarnął ten dorobek ludzkości i oczekiwał upowszechnienia tej postawy. Czyż nie ma w tym nastawieniu czegoś z Pansofii J. A.
Komeńsklego?

Podsumowując problem recepcji teleologii Wrońskiego trzeba powiedzieć, że poza nieco nadmiernie krytycznym Kolbuszewskim oraz Jastrzębcem-Kozłowskim pozostali autorzy nie zamierzali zgłębiać meandrów myśli Wrońskiego i zadowolili się ich prostą - czasem nietrafną

16 Wedlug d. Bulandy cel czlowieka u Hoene-Wrónskiego ma chirakler teoretyczny i zarazem finalny (równoznaczny z celern Iudzkosci). J. Bulanda, Wsród poglqdow pedagogicznych B. F. Thentowskiego. Ropcyce 1930

17 H. Rowid, op. cit, s. $262-263$.

IE Wydaje się, ze Wró́ski w swojej filozofii przywolywal dawnł antycznq teorię racjonalizmu etycznego przechowana w christianizmie za posrednictwem こllozo[ij neoplatońskjej. Na te powiązania wskazuje także Jastrzebiec-Kozlowski wyjaśniając pojęcie mesjanistycznosici przez postawienje znaku równości między autonomicznymi celami czlowjeka i absolutnymi celami Boga
"N. Kolbuszewski, op. cit, s 150 . 
- syntetyczną wykładnią. Tymczasem pedagogika ta pomieścila w sobie zarówno genialne przeczucie idei pedagogicznych następnego stulecia jak i przetworzone koncepcje przeszłości. Wrońskiego trzeba czytać z podręcznikiem historii filozofii i pedagogiki w ręku, by uświadomić sobie jak wielką SYNTEZĄ była jego Filozofia Pedagogii. Abstrakcyjność, hipertrofia racjonaliz$\mathrm{mu}$, uniwersalizm sq $\mathrm{w}$ tym samym stopniu skrajne co cenne.

Wraz z teorią celów narzuca się niemal w sposób konieczny analiza założeń psychologii Wrońskiego. Dla niego bowiem, jak dla Kanta, człowiek jest istotą „wielopostaciową", zróżnicowaną wewnętrznie. Chronologicznie rzecz biorąc jako pierwszy tym zagadnieniem zainteresowal się Kolbuszewski, prezentując fazy rozwoju świađomości. Wyróżnił za Wrońskim świadomość UCZUCIOWA (ja empiryczne), następnie POZNAWCZA, ROZUMIEJACA ponad nimi rozpościerać się miała świadomość GENIUSZA i ABSOLUTNA. Do tego samego zagadnienia nawiązal Jastrzębiec-Kozłowski nadając tym samym fazom (stopniom) inne, uzupełniające desygnaty. Tak więc świadomość uczuciowa to jaźn empiryczna, a jej cechą konstytutywną - bierność. Druga to jaźń logiczna, ta z kolei jest czynną. Po nich następuje transcendentalna wyrażająca się przez zasadę krytyczną, następną należałoby - autor tego nie czyni - chyba nazwać twórczą, wyrażającą się przez potencjalność. Najwyższa postać jaźni - absolutna znów przez Jastrzębca-Kozłowskiego nazwana jest transcendentalna, a jej ekspresja dokonuje się poprzez absolutne stworzenie rozumu ${ }^{20}$. Tenże autor podkreśla dynamiczny charakter teorii Wrońskiego, wydobywając $z$ niej dwa procesy rozwoju świadomości: heteronomiczny i autonomiczny. Nie dostrzega jednak redukcyjnego i schematycznego podłoża filozofii pedagogiki Wrońskiego.

Innym zagadnieniem żywo wiążącym doktrynę Wrońskiego $\mathrm{z}$ jej międzywojenną recepcją i współczesnymi problemami tożsamości pedagogiki - a w takiej perspektywie badawczej tkwi realna wartość uprawiania szeroko rozumianej historii wychowania - jest zagadnienie dychotomii swobody i przymusu w wychowaniu ${ }^{21}$.

Zdaniem Jastrzębca-Kozłowskiego najbardziej adekwatnie prezentującego Filozofię Pedagogii Wrońskiego wolność i konieczność sq atrybutami tej samej rzeczywistości, jaką jest „Arcy-Absolut". Konieczność wyraża pierwiastek bytowy, wolność - wiedzę. Zagadnienie to ponownie sprowadza nas do centralnych pojęc doktryny Wrońskiego: Prawa Tworzenia (usystematyzowana wolność) i Prawa Postępu (usystematyzowana konieczność). Walser, co trzeba wyraźnie podkreślić, budując własną koncepcję wychowania w oparciu o system Hoene-Wrońskiego rozstrzygnął problem dychotomii wolności i przymusu przez odwołanie się do harmonii między: „karnością wynikającą z obowiązku (konieczność obiektywna), a wolnym wyborem (fantazja obiektywna)m22. Czy jednak ten enigmatyczny punkt widzenia jest adekwatny? - to pytanie otwarte. Czy obowiązek to $w$ istocie to samo, co Prawo Tworzenia? Raczej nie. Myśl Wrońskiego zdaje się krążyć bliżej imperatywu kategorycznego I. Kanta niż potocznie (heteronomicznie) rozumianego obowiązku, będącego częściej wyrazem samowoli czynników określających jego jakość, niż „prawa moralnego w nas". Walser daje interpretację uproszczoną, populistyczną - w więc odartą $z$ wszystkiego co abstrakcyjne i nienamacalne. W przekonaniu o błędności takiej wykładni utwierdzić może krótkie ale znaczące sformułowanie B. Gaweckiego. Według niego Hoene-Wroński „nawiązuje do Kanta

${ }^{20} \mathrm{Cz}$ Jastrz̨̧biec-Kozlowski, op. cit., s. 230 -231. F. Walser, który podjąl sję próby przelożenia teorii Wrońskiego na język praktyli pedagogicznej uważał, że „system oparty jesı na rozwoju sześciu postaci, czy sześciu celów świadomości: 1. świadomości swej osobistej, niezależnej siły, 2 dobra, 3. prawdy, 4. piękna, 5. ładu, 6. harmonii"”. Odpowiednio do nich wychowanie szkolne mialoby rcalizować 4 cele: zrozumienie ilości, właściwości, prawdy i piękna, a na szczeblu szkoły średniej i unjwersyletu - ladu i harmonii. F. Walser, op. cit., s 196-199, 241, 246.

${ }^{21}$ Badanie myśli pedagogicznej - dzjedziny historii wychowania, zakładając jej definicję wg Compayre'a j Truchima, to badanje w istocie świadomości, która jest bardżej swobodna, mniej uwarunkowana zewnętrznymi czynnikami, a więc bardziej uniwersalna niż historia oświaly. Swiadomość pedagogiczna, jak każdy inny rodzaj świadomości danej dziedziny kultury, ma swoje odrębne właściwości. Specylikq reflekji historycznej w pedagogice jest to, ìe czlowiek łązy penelrację przeszlości z tworzenjem, nierealnej przecież, bo polencjalnej, wizji tego, co dopiero ma nastąpić. Meandry życja wykrzywią myśl ale jednocześnje ją uwiecznią - zachowując te niezrealizowane jej aspekty, k tóre w nowych czasach sq motorem ludzkiej aktywności. Właściwie w tym kontekście można mówić o bistorii pedagogii w odróżnieniu od hislorii pedagogiki.

${ }^{22}$ F. Walser, op. cit. s. 200-201. 
pisząc o "filozofii pedagogii" w Reformie absolutnej wiedzy ludzkiej: Kant ustalił moralność (moralne jest to, co może stać się prawidłem postępowania powszechnego), ale jej nie ugruntował; dał prawo moralne, ale pominał ugruntowanie rozumowe tego prawa. Ugruntowanie to dał Wroński, ustalając cel absolutny ludzkości: „stworzenie się własne człowieka” (...) Dają się w ramach filozofii Wrońskiego uzasadnić następujące reguły ogólne postępowania wychowawczego: 1. należy odslaniać młodzieży nieobecność wszelkiej wartości absolutnej w celach fizycznych albo ziemskich, 2. pobudzać ją do szukania celów wyższych, godniejszych przyrody jej rozumowej, 3. uszlachetniać ją widokiem przyszłości pełnej dostojeństwa"23. Tak więc wolność nie jest identyczna z grą wyobrażni - abstrahując od obiektywnosci fantazji - lecz wyrażonym w ludzkich czynach Prawem Tworzenia.

$\mathrm{Na}$ zakończenie warto przyjrzeć się ocenom Wrońskiego formułowanym w okresie międzywojennym, a jeszcze bardziej próbom odczytania go na nowo, widząc w nim prekursora ówczesnych poszukiwañ ${ }^{24}$. Dla wspomianego wyżej Gaweckiego twórczość Wrońskiego czeka na swego odkrywcę. Przewidywał, że jego system wyciśnie znaczące piętno na kulturze polskiej i światowej. Nie inaczej pisał o nim Kolbuszewski: „Wroński, o którym dotąd w historii pedagogii ghucho, a w historii filozofii niewiele lepiej, objawia się jako jeden z genialnych teoretyków, co kładą podwaliny pod filozofię pedagogii (...) Nikt przed nim i nikt po nim nie ujął tak głęboko celu

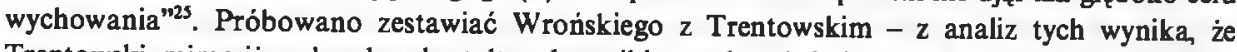
Trentowski, mimo iż wpłynął na kształt pedagogiki narodowej silniej - oparł ją na skromniejszych przesłankach filozoficznych aniżeli "geniusz romantyzmu", za jakiego poczytywał go Kolbuszewski. Obie filozofie i obie postacie posiadają kilka wspólnych punktów - jest to jednak problem na osobną zupełnie rozprawę. Róźnilo ich znacznie więcej - a jeśli spojrzymy na kręgi kulturowe, $\mathrm{z}$ którymi się identyfikowali, to można przyjąć, że propagowany przez nich mesjanizm i ich własna dialektyka splatały im figla. Nie zwyciężył w nich pierwiastek słowiański - zorientowani, jeden na kulture francuską drugi germańską - nie znaleźli wspólnego języka.

Spośród autorów interpretujących poglądy pedagogiczne Wrońskiego z interesującej nas perspektywy na uwage zasługuje Rowid. Uznał on cel wychowania sformulowany przez Wrońskiego za odpowiadający ówczesnym postulatom pedagogicznym. Według niego "w budowaniu nowej szkoły - szkoły twórczej - przyświecać nam winny ideały pedagogiki Hoene-Wronskiego i Trentowskiego - ideał człowieka zdolnego do ciąglego doskonalenia się wewnętrznego i człowieka twórczego"26. U Kolbuszewskiego, który swoje rozważania kierował w stronę porównania Wrońskiego z Mickiewiczem zaakcentowana została myśl, której najbliższa byłaby teoria rekapitulacji. „Wychowanie człowieka musi być upodobnione do wychowania ludzkości w postępach jej rozwoju. Musi więc człowiek wchłonąć w siebie całą kulturę dotychczasowa, poznać drogi ludzkości i na tym podłożu budowac kulturę nową"27.

Rekapitulując dotychczasowe nasze poszukiwania musimy odpowiedzieć na pytanie o ich wyniki. Przede wszystkim narzuca się konstatacja, że tak jak w okresie międzywojennym, tak i współcześnie brak Wrońskiego w nauce o wychowaniu. Karygodna wręcz jego nieobecność w polskich podręcznikach do historii wychowania daje złe świadectwo współczesnemu stanowi tej nauki ${ }^{28}$. Drugie spostrzeżenie dotyczy literatury poświẹconej Hoene-Wrońskiemu. Jego twórczość

${ }^{23}$ B. Gawecki, Pierwiastek filozoficzny w pedagogice. "Przeglad Pedagogiczny" 1922, z 4, s. $264-265$.

${ }^{34}$ Dzis $w$ dobie przebudowy "pedagogicznej historii wychowania" taki model rekonstrukcji dzjejów, klóry wychodzi $z$ relrogresyw nej metody badań staje się coraz bardzjej popularny. Jest on wywodzony z zachodniej, spotecznej hislorii wychowania, ale $\mathrm{ma}$ on swych reprezentantów w ojczys tej tradycji.

29. Kalbuszewski, ap. cil, \& 154.

${ }^{26}$ H. Rowid, ap. cit, \& 266 .

"S. Kolbuszewski, op. ciL a 150 .

29 Próbę odpowiedzi na pytanie a przyczyny tega zjawiska majdzie czytelnik w kilku pracach autora niniejszej rozprawy, min: Historia doktryn pedagogicznych - niepokoje interpretacyine (W:) red. T, Jalmuing, I. G. Michalscy, Metodologia w badaniach naukawych historil wychowania. Lódź 1993; O badaniu historil doktryn pedagogicznych. (W:) Biale plamy w najnowszej historit wychowania Warszawa 1993; Progi i hariery wspólczesnej historil myśli pedagogicznej. Biulelyn Hislorii Wychowanja" 1994, nr 1 , s. 3 - 5 . 
poddana została niepetnej, fragmentarycznej analizie. Poza kilkoma sugestiami nie badano Wrońskiego z punktu widzenia ówczesnych potrzeb edukacyjnych, dominował $w$ prezentacji Filozofii Pedagogii typ raczej opisowy niż krytyczny; układ częściej chronologiczny niż problemowy, stąd i sam Wroński pozostał samotną wyspa bez szerszych odniesien. Zaskakującym paradoksem jest fakt, że wysokie oceny umysłow ości Wrońskiego szły w parze z milczeniem o nim w ówczesnej (a tym bardziej we współczesnej) historii wychowania. Będąc rzeczywiście genialnym prekursorem wielu poczynań następnego stulecia nie powinien zostać zapomniany. W czasopiśmiennictwie, które najszybciej reagowało na nowe trendy, brak, poza zbyt dowolną interpretacją Walsera, głębszych prób operacjonalizacji filozofii wychowania Wrońskiego. Wydaje się również, i to dotyczy także prezentowanych rozpraw, że nie doceniano oryginalności i samodzielności tego mesjanisty. Jego system filozofii uniwersalnej nie da się sprowadzić (zredukować) do jakiejś źródłowej doktryny pedagogicznej na zachodzie. Był on samotnym żeglarzem zarówno w życiu codziennym, jak i na polu nauki. W nauce - jak pisal Hessen - pytania sq te same, zmieniają się tylko odpowiedzi. Wroński sięgnął do jądra problematyki pedagogicznej i dał swoją odpowiedź na pytanie o stałość i zmienność w naukach pedagogicznych - pytanie, które nadal pozostaje otwarte.

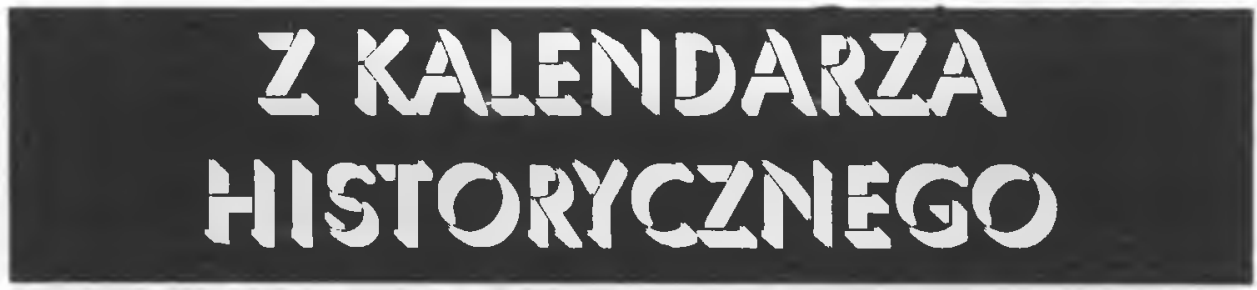

Kazimierz Denek

Poznań

\section{Trzy ćwierćwiecza krajoznawstwa i turystyki w polskiej szkole}

Nic tak dobrze nie charaktaryzuje natury zjawiska społecznego, jak poznanie przyczyn jego powstania, ewolucji, tradycji. Zatem przyjrzyjmy się historii krajoznawstwa i turystyki w naszym kraju ze szczególnym uwzględnieniem jednego $z$ jej nurtów, jakim jest szkolny ruch krajoznawczo-turystyczny. Nie sposób bowiem mówić o współczesnym kształcie tego ruchu bez próby spojrzenia wstecz $i$ odwołania się do przeszłości. Uwzględnienie przeszłości szkolnego ruchu krajoznawczo-turystycznego w Polsce w procesie dydaktyczno-wychowawczym prowadzonym w aspekcie krajoznawstwa $\mathrm{i}$ turystyki wynika $\mathrm{z}$ poczucia ciąglości tej pracy. Jest ono spoiwem dokonań kilku pokoleń, wyrazem szacunku i poszanowania dla wartości, które w sposób trwały i chlubny zapisały się w kronikach oświaty oraz historii krajoznawstwa i turystyki w Polsce.

Krajoznawstwo i turystyka w Polsce moga poszczycic się wybitnymi postaciami. Wytyczyły one drogi, formy i metody postẹpowania. Dążąc do upowszechnienia idei krajoznawstwa i turystyki, zwłaszcza wśród młodzieży, powinniśmy znać tradycje tego ruchu i szczególnie tych, którzy swą pracą wnieśli twórczy wkład w rozwój poznawania ojczystego kraju i przygotowali grunt dla pracy przyszłych pokolen. Historia krajoznawstwa i turystyki w Polsce jest niezwykle ciekawa i pouczająca. Stanowić może doskonały temat pracy szkolnych kół 